УДК 621,521

\title{
VERIFICATION OF FLUID FLOW CALCULATIONS IN VORTEX CHAMBER SUPERCHARGERS
}

\author{
A. Rogovyi, Assoc. Prof., Ph. D. (Eng.), \\ Kharkov National Automobile and Higway University
}

\begin{abstract}
On the basis of numerical modeling (URANS) by means of specialized program complexes verification of fluid flow calculation in vortex chamber superchargers was carried out. It is determined that it is better to apply a model of incompressible liquid for calculations with the turbulence model, considering the streamline curvature and system rotation (SST curvature correction).
\end{abstract}

Key words: vortex chamber supercharger, numerical calculation, suction discharge, streamline curvature, correction, turbulence model.

\section{ВЕРИФИКАЦИЯ РАСЧЕТОВ ТЕЧЕНИЙ В ВИХРЕКАМЕРНЫХ НАГНЕТАТЕЛЯХ}

\author{
А.С. Роговой, доц., к.т.н., \\ Харьковский национальный автомобильно-дорожный университет
}

\begin{abstract}
Аннотация. Путем сравнения с экспериментальными данными проведена верификаџия математического моделирования течения в вихрекамерных нагнетателях на основе использования специализированных программных продуктов. Получено, что для расчетов лучше применять модель несжимаемой жидкости с моделью турбулентности, учитывающей кривизну линий тока и вращение потока.
\end{abstract}

Ключевые слова: вихрекамерный нагнетатель, численные расчеты, расход всасывания, кривизна линий тока, поправка, модель турбулентности.

\section{ВЕРИФІКАЦІЯ РОЗРАХУНКІВ ТЕЧІЇ У ВИХОРОКАМЕРНИХ НАГНІТАЧАХ}

\author{
А.С. Роговий, доц., к.т.н., \\ Харківський національний автомобільно-дорожній університет
}

Анотація. Шляхом порівняння з експериментальними даними проведено верифікацію математичного моделювання течії у вихорокамерних нагнітачах на основі використання спеціалізованих програмних продуктів. Отримано, що для розрахунків краще застосовувати модель нестисливої рідини з моделлю турбулентності, щэо враховує кривизну ліній струму й обертання потоку.

Ключові слова: вихорокамерний нагнітач, числові розрахунки, витрата всмоктування, кривизна ліній струму, поправка, модель турбулентності.

\section{Introduction}

Today, the methods of numerical calculations of various fluid and gas flows have become widespread. However, despite significant growth of computer power, turbulent flows calculation, remains one of the challenges of fluid dynamics computation [1]. Though, recently its applica- tion has increased in the methods of direct numerical simulation (DNS) and large eddy simulation (LES), their wide practical application is observed in hydroaerodynamics problems solution, for today is practically not possible, owing to extreme computing work content $[2,3]$. 
Therefore, at calculations of difficult flows, it is necessary to use the semiempirical methods basing on Reynolds averaged Navier-Stockes equations. Semiempirical models and their updates exists much enough and, unfortunately, for today, there is no universal model of this kind, besides there is a pessimistic appraisal of that the look-alike universal model will be hardly constructed [3]. Therefore, at study of such and such pneumatic and hydraulic units and application packages of CFD, first of all, it is necessary to effect verification of used models for selection approaching turbulence model with the minimum errors from experimental data.

\section{Analysis of publications}

In many industries, working conditions are difficult and use of pumps and compressors vane and displacement types leads to the raised expenses for equipments replacement and a manufacture stop owing to the raised deterioration of mobile working bodies and sealing [4]. Besides, influence of vibration, temperatures, presence of abrasive particles and liquids chemical aggression reduce efficiency and worsen performance data of the superchargers used in such service conditions [5].

It is possible to reduce the working costs by using of more reliable and durable superchargers which the superchargers concerning the fluidics are: jet pumps [6], vortex injectors [7] and vortex chamber superchargers [8]. Jet devices possess high indicators of reliability and durability owing to absence of mobile working parts, are widely used in difficult service conditions, but have low enough indicators of efficiency which do not exceeding $30 \%$ [9].

It is possible to improve power efficiency indicators , using more perfect ways of energy transfer in designing of jet devices which are developed vortex chamber superchargers [10]. Owing to a combination in their work not only energy transfer by means of a turbulent exchange, but also action of centrifugal force it is possible to raise efficiency, especially at pumping dry substances [11]. These superchargers concerning the fluidics, possess high indicators of reliability and durability, thanks to absence of mobile parts [12].

The first mentions about vortex chamber superchargers have appeared in publications [13, 14], i.e. they yet have no wide spreading in the in- dustry and large-scale researches including by means of computing methods, practically it was not spent. Thus, actual there is a problem of model turbulence selection for simulation of fluid flows in vortex chamber superchargers (VCS) for maintenance of the minimum calculation errors and parameters prediction of a fluid flow.

Features of working process in VCS, first of all, are connected with hydrodynamic features of the swirled flows, such as vacuum presence on an axis of a rotating flow and excess pressure upon peripheries [15]. Hence, turbulence model selection for fluid flow calculation in VCS demands from model of the adequate description and effects prediction of the swirled flows [16]. For today, many researches concerning a choice of turbulence models for various devices at which there are confined vortex: cyclones [17], vortex valves [18], vortex pipes and vortex injectors. In the majority of the works devoted to the description of fluid flows in vortex devices authors come to a conclusion that the most suitable from the computing duration and by criterion of a calculations error minimality the simulation model on a basis Reynolds averaged Navier-Stockes equations with use SST turbulence model with rotation-curvature correction [19]. Comparison of fluid flows simulation results in vortex chamber superchargers with use of various turbulence models and their updatings for today was not spent.

\section{Analysis and problem statement}

The aim of the work is verification of fluid flows mathematical modelling in vortex chamber supercharger on the basis of the numerical decision of the Reynolds averaged NavierStockes equations by means use specialised program complexes.

\section{Materials and methods}

Verification of numerical researches was made by comparison of experiment results with CFD simulations in program complex OpenFoam [20]. Comparison was made on integrated parameters such as the fluid flow rate on an input channel of the device (the supply fluid flow rate), the fluid flow rate on an exit from the device and the fluid flow rate which is pumped over VCS. Comparison on integrated parameters is dictated by that essential nonstationarity fluid flow and vortex core precession in the chamber 
leads to that fluid flow kinematic characteristics in the device change the values, therefore to measure them and to make comparison difficult enough. Except a quantitative estimation of integrated parameters calculation errors, qualitative comparison of fluid flow patterns for what experimental sample VCS has been executed with transparent face covers was made. The estimation of calculation errors is executed for two designs VCS: with and without radial diffuser, installed in the exit axial channel (fig. 1).

Experimental setup for physical research included vortex chamber supercharger, blower, receiver and measuring equipment. Pressure in channels was measured by manometers, ambient temperature - mercury thermometers, the fluid flow rates in channels - flowmeters. Air was the working and pumped over medium in experimental researches.

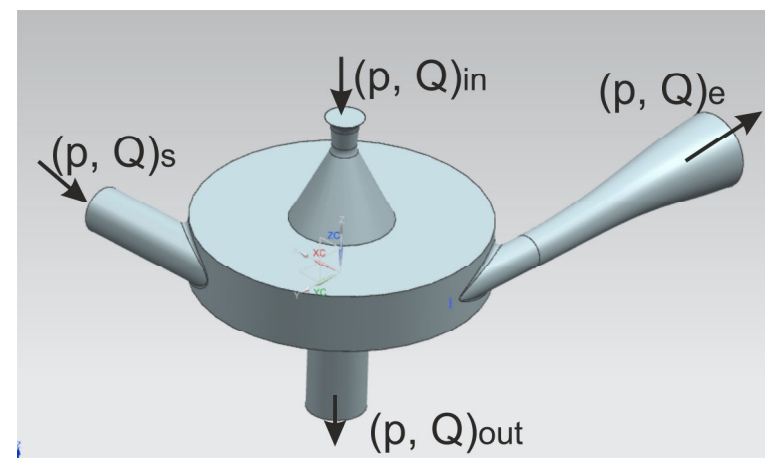

a

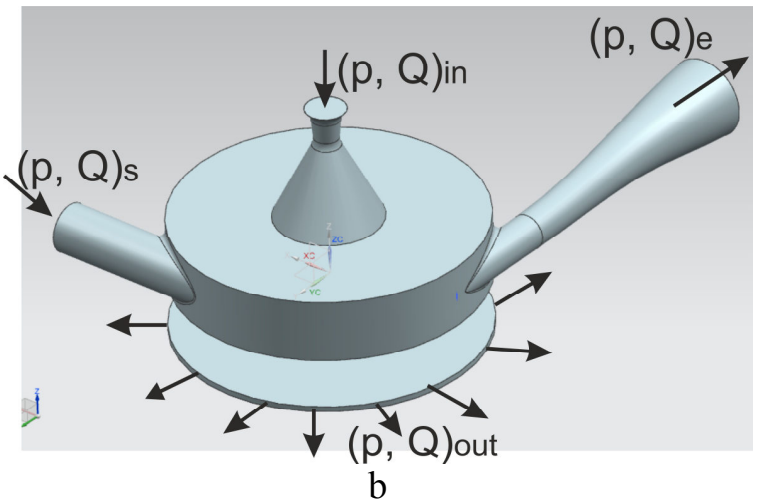

Fig. 1. 3D VCS model: a - VCS without radial diffuser; VCS with radial diffuser, installed in the exit axial channel

On the basis of the article analysis [2, 3, 16-19], devoted CFD modeling of the swirled flows in various devices one can draw a conclusion that to the best on calculation time and accuracy of a kinematic parameters prediction is SST turbulence model with rotation-curvature correction [19]. Application of more perfect models DNS, LES, and also hybrid demands considerable time expenses and high-efficiency computer systems [2] that complicates carrying out of a great number of calculations by optimization of a superchargers flowing part. Therefore in the given work it was used SST turbulence model and its correction for definition of the most suitable to flow simulation in VCS. Following calculation models were compared: coarse NCF - calculation of an incompressible liquid on a coarse mesh, coarse NCF-CC - an incompressible liquid on a coarse mesh taking into account the rotation-curvature correction, coarse $\mathrm{CF}-\mathrm{a}$ compressed liquid on a coarse mesh, coarse CF$\mathrm{CC}-\mathrm{a}$ compressed liquid on a coarse mesh with curvature cirrection, NCF - an incompressible liquid, NCF-CC - an incompressible liquid with curvature correction, $\mathrm{CF}$ - a compressed liquid, $\mathrm{CF}-\mathrm{CC}$ - a compressed liquid with curvature correction.

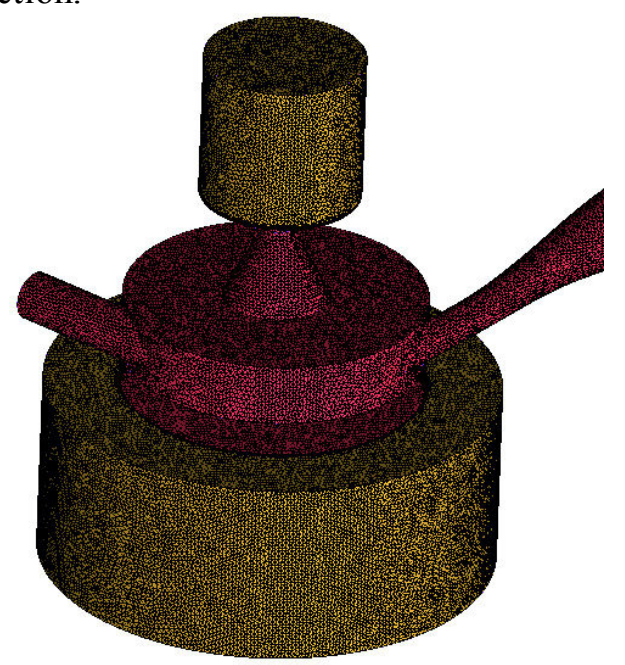

a

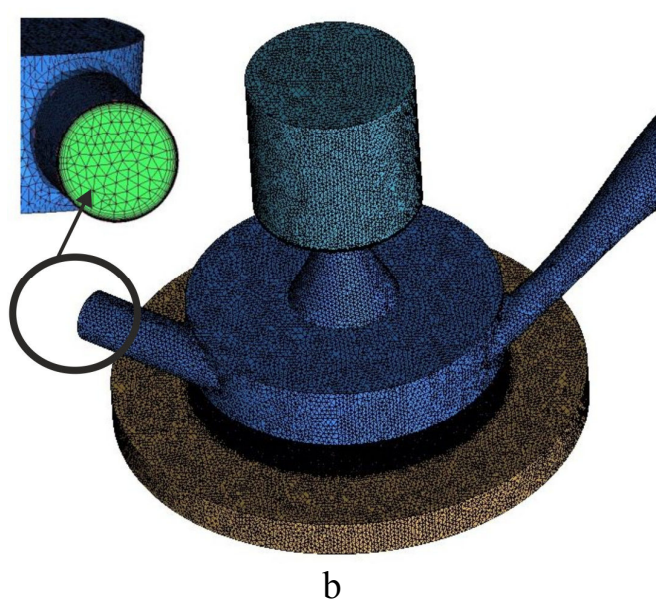

Fig. 2. Design mesh of VCS: a - without radial diffuser; $b$ - with radial diffuser

The mesh (fig. 2) consisted of 7 million elements for simulation VCS with radial diffuser and 4,5 million elements for VCS without radial 
diffuser, and has been constructed so that to provide parameter $\mathrm{Y}+<2$. The greater number of elements for the device with diffuser is caused by reduction of the elements size in diffuser owing to small width of the channel (fig. 2, b). The choice of elements number has been dictated by comparison of calculation results on more coarse meshes and meshes with a great number of elements (a 15 million order). As a result of calculations it has been received that use of meshes with number of elements more than 7 million not rationally, owing to absence of the big differences in errors, but considerable computing expenses.

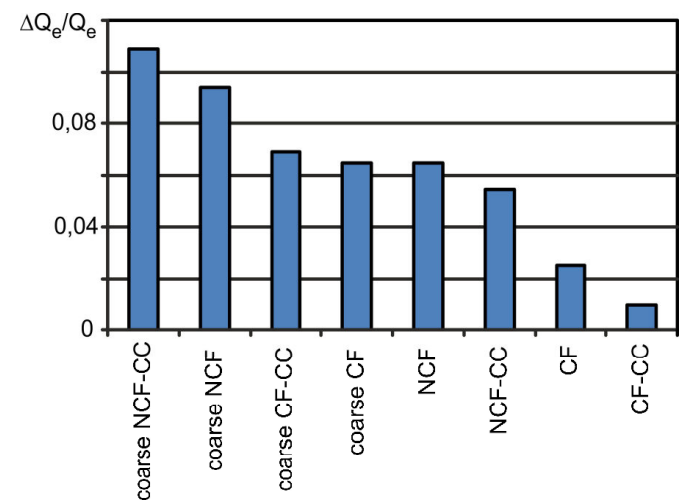

a

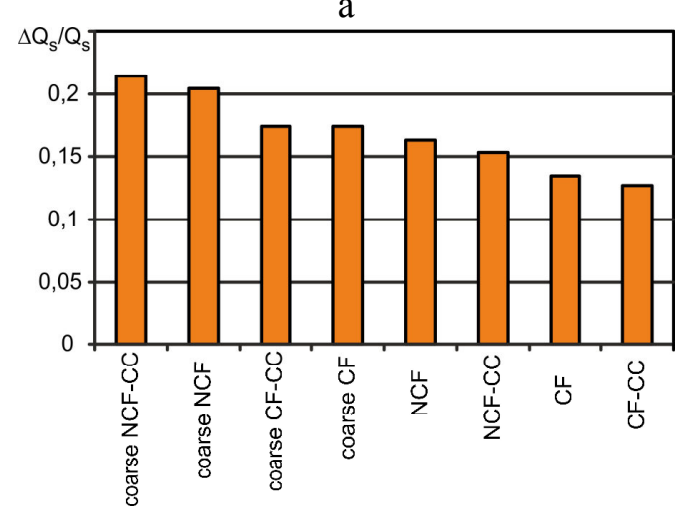

b

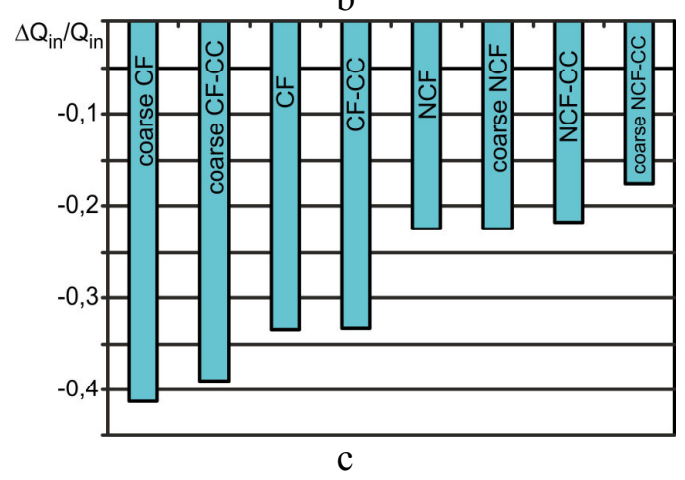

Fig. 3. Errors of fluid flow calculation results in VCS with the radial diffuser: a - fluid flow rate in the exit channel; $b$ - fluid flow rate in the supply channel; $\mathrm{c}$ - fluid flow rate sucked in the device
At the task of boundary conditions of axial exits and vortex chamber entries that in the swirled flows pressure is distributed on stream radius was considered. Therefore the rated operating conditions has been increased and exit boundary conditions on new boundary face where pressure is almost equal to zero are set and does not change on radius [12].

\section{The main results of the research}

On fig. 3 results of fluid flow calculations comparison in vortex chamber superchargers with the radial diffuser and the integrated parameters gained experimentally are resulted.

As it is possible to see from fig. 3, models taking into account curvature of streamlines and rotation have the least errors. At application of these models of compressible liquid calculation of the fluid flow rate on an exit and the supply channels makes an order of $10 \%$. Incompressible liquid models give for these two fluid flow rates an error on $2-3 \%$ the big. Differently with the sucking fluid flow rate in the device. Here, models of incompressible liquid calculation taking into account the rotation-curvature correction have the minimum error, and this error considerable - exceeds $15 \%$. The calculations spent for compressible fluid led to increase in a calculation error of the sucking fluid flow rate in the device which made more than $30 \%$. From what it is possible to draw a leading-out that it is better to apply model of incompressible liquid to calculations VCS with model of the turbulence considering curvature of streamlines and rotation.

The difference in calculation errors of sucking fluid flow rate originates owing to different magnitude of vacuum on an apparatus axis (fig. 4). On fig. 4 pressure patterns in VCS with and without the radial diffuser are resulted. Owing to nonstationarity fluid flow in VCS, and also a vortex core precession [21] calculations were spent in transient statement. At comparison of the patterns resulted on fig. 4 it is possible to notice that the greatest vacuum on an axis is gained at calculation of model NCF-CC shown on fig. $4, \mathrm{~b}$ that explains the least sucking fluid flow rate error. Thus, than more precisely the model predicts vacuum on an axis, especially exact there are calculations as a whole.

Besides, correct prediction of vacuum on an axis is necessary for the further calculations of gas bubble behaviour getting in the vortex chamber [22]. 
Rotation-curvature correction use allows to compute the sucking fluid flow rate on 5-15\% more precisely, in connection with more exact calculation of vacuum magnitude on an axis.

On fig. 5 results of fluid flow pattern calculations in vortex chamber superchargers without the radial diffuser and the integrated parameters gained experimentally are resulted.

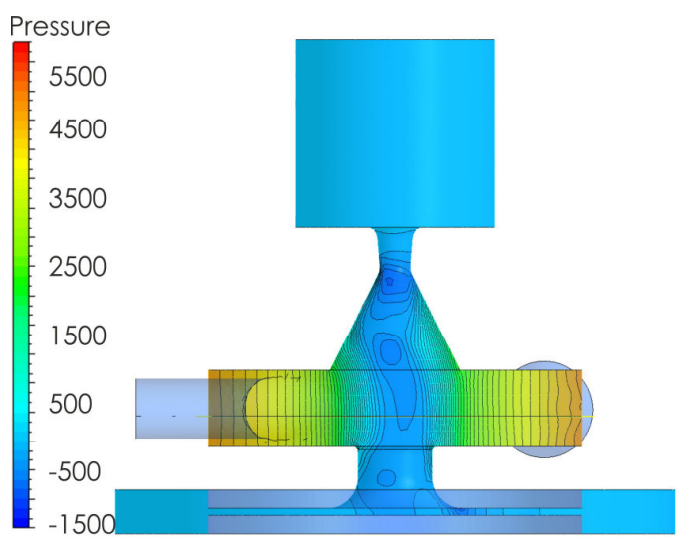

a

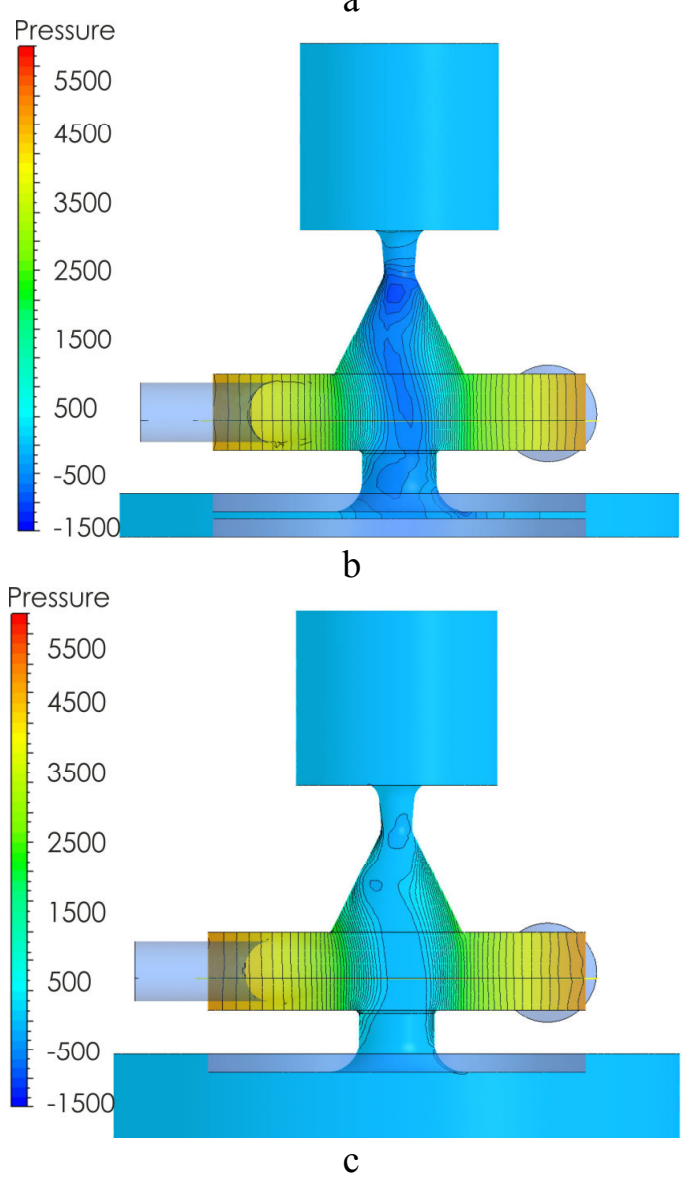

Fig. 4. Design distributions of pressure: VCS with diffuser, model CF-CC; VCS with diffuser, model NCF-CC; VCS without diffuser, model NCF-CC
As it is possible to see from fig. 5, models taking into account streamline curvature have the least error. Unlike calculations VCS with radial diffuser, here not all models could predict presence sucking fluid flow rate in the device. So, for example, calculation on model coarse $\mathrm{CF}$, has led to the negative sucking fluid flow rate, i.e. to ejection of a working flow from the vortex chamber outside.

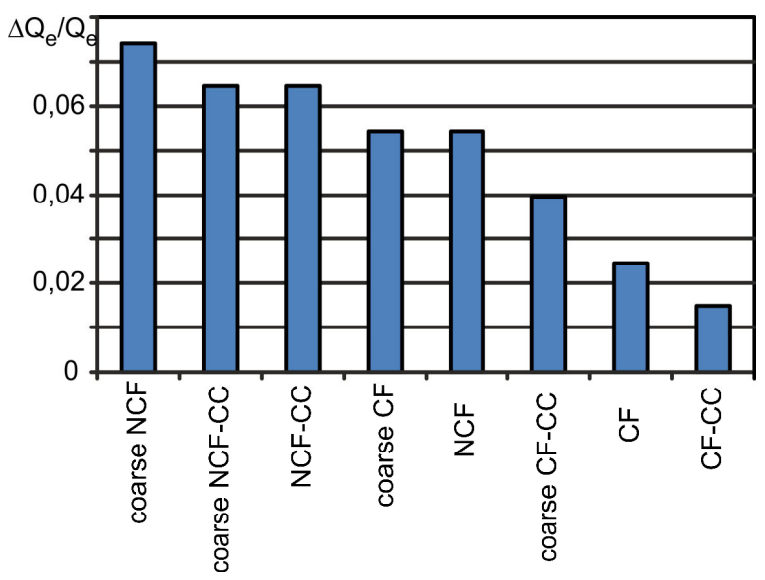

a

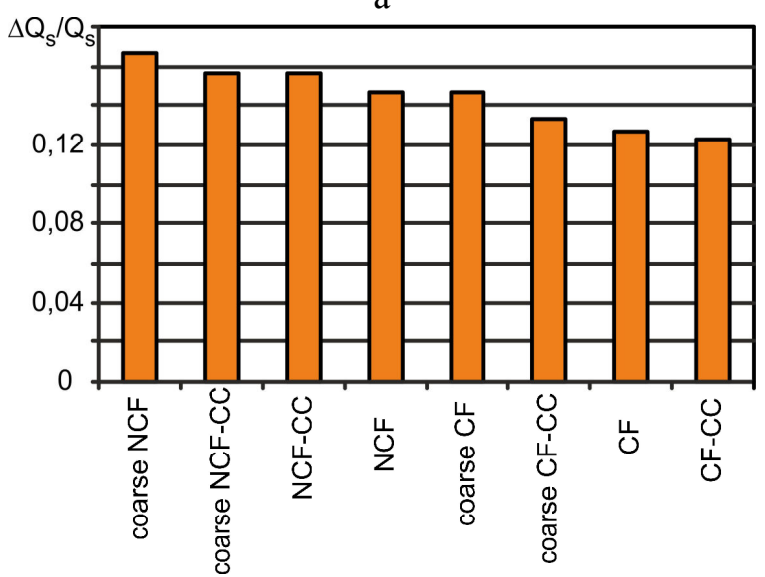

b

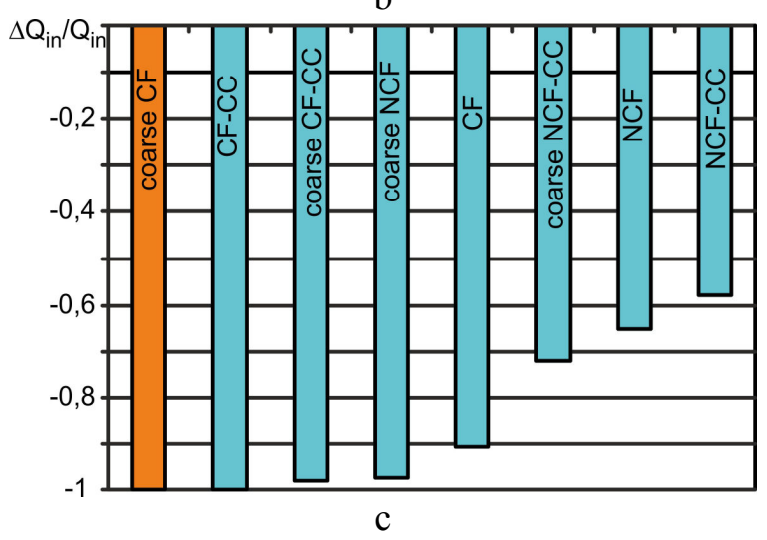

Fig. 5. Errors of fluid flow calculation results in VCS without the radial diffuser: a - fluid flow rate in the exit channel; $b$ - fluid flow rate in the supply channel; c - fluid flow rate sucked in the device 
At calculations VCS without the radial diffuser, simulation inaccuracy of the sucked fluid flow rate more than inaccuracy for VCS with the diffuser. For such construction of a supercharger crucial there is use of model with rotationcurvature correction since the sucking fluid flow rate, for many calculation models, on order surpasses the sucking fluid flow rate calculated without curvature correction.

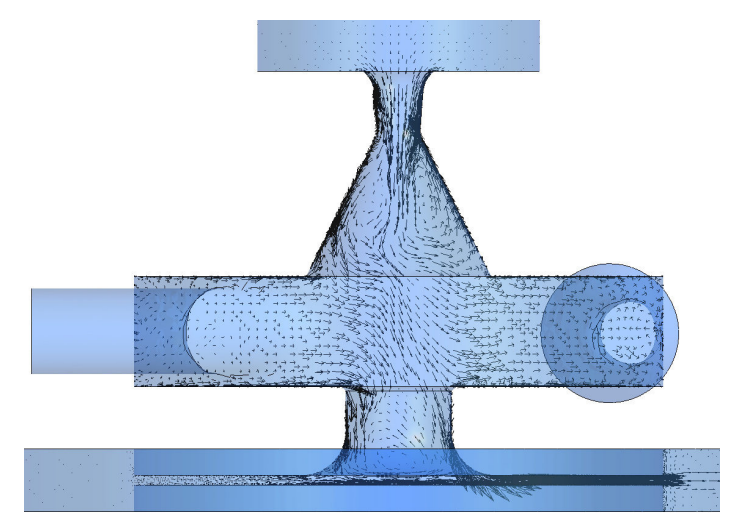

$\mathrm{a}$

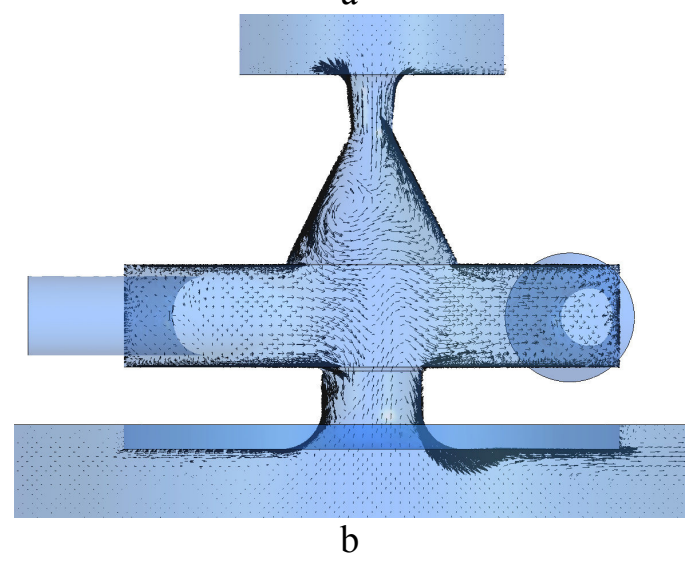

Fig. 6. Profiles of velocity in VCS: a - with the radial diffuser; $b$ - without a radial diffuser

Originating negative the sucking fluid flow rate is well visible on fig. 6 where the field of velocity vectors in VCS is demonstrated. The sucking fluid flow rate discharge rate in supercharger formed on a axial of the vortex chamber, thrown out flow of the device - on periphery of the axial channel of an input that it is possible to see on fig. $6, b$.

\section{Conclusions}

On the basis of the numerical decision of the Reynolds averaged Navier-Stockes equations by means use specialised program complexes verification of mathematical modeling of a fluid flow in vortex chamber supercharger is effected.
It is better to apply model of incompressible fluid to calculations VCS with turbulence model to the effects of streamline curvature and system rotation.

Use of rotation-curvature correction allows to simulate the fluid flow rate of suction on 5-15\% more precisely, owing to more exact calculation of vacuum magnitude on axis.

At calculations VCS without a radial diffuser, simulation inaccuracy of the sucking fluid flow rate more than inaccuracy for VCS with a diffuser. For such construction of a supercharger crucial there is use of model with rotationcurvature correction since the sucking fluid flow rate, for many calculation models, on order surpasses the sucking fluid flow rate calculated without curvature correction.

\section{References}

1. Приходько А.А. Компьютерные технологии в аэрогидродинамике и тепломассообмене / А.А. Приходько. - К.: Наукова думка, 2003. - 380 с.

2. Солодов В.Г. Современное состояние проблемы моделирования крупномасштабной турбулентности / В.Г. Солодов // Вісник НТУ «ХПІ». Серія: Гідравлічні машини та гідроагрегати. - 2016. - № 20 (1192). - C. 108-115.

3. Гарбарук А.В. Моделирование турбулентности в расчетах сложных течений: учебное пособие / А.В. Гарбарук, М.Х. Стрелец, М.Л. Шур. - С.Пб.: Изд-во Политехн. ун-та, 2012. - 88 с.

4. Syomin D. Vortex mechanical devices in control systems of fluid mediums / D. Syomin, V. Pavljuchenko, Y. Maltsev, A. Rogovoy, D. Dmitrienko // Teka Komisji Motoryzacji i Energetyki Rolnictwa. - 2010. Vol. 10. - P. 440-445.

5. Баранов Ю.Д. Обоснование параметров и режимов работы систем гидротранспорта горных предприятий / Ю.Д. Баранов, Б.А. Блюсс, Е.В. Семененко, В.Д. Шурыгин. - Днепропетровск: Новая идеология, 2006. -416 с.

6. Соколов Е.Я. Струйные аппараты / Е.Я. Соколов, Н.М. Зингер. - 3-е изд., перераб. - М.: Энергоатомиздат, 1989. $352 \mathrm{c}$.

7. Суслов А.Д. Вихревые аппараты / А.Д. Суслов, С.В. Иванов, А.В. Мураш- 
кин, Ю.В. Чижиков. - М.: Машиностроение, 1985. - $256 \mathrm{c}$.

8. Syomin D. Features of a working process and characteristics of irrotational centrifugal pumps / D. Syomin, A. Rogovyi // Procedia Engineering. - 2012. - Vol. 39. P. 231-237. doi: 10.1016/ j.proeng. 2012.07.029.

9. Роговой А.С. Энергетическая эффективность пневмотранспортних установок / А.С. Роговой // Вісник СНУ ім. В. Даля. - 2016. - №1 (225). - C. 189-196.

10. Syomin D. Power characteristics of superchargers with vortex work chamber / D. Syomin, A. Rogovoy // Teka Komisji Motoryzacji i Energetyki Rolnictwa. 2010. - Vol. 19. - P. 232-240.

11. Сёмин Д.А. Экспериментальные исследования характеристик струйно-вихревого насоса / Д.А. Сёмин, А.С. Роговой // Вісник СумДУ. - 2005. - 12(84). C. 64-70.

12. Роговий А.С. Удосконалювання енергетичних характеристик струминних нагнітачів: дис... канд. техн. наук: 05.05.17 / А.С. Роговий. - Луганськ, 2007. - $193 \mathrm{c}$.

13. Beck Jeffrey L. Vortex injection method and apparatus. U.S. Patent No. 4,449,862. 22 May 1984.

14. Деклараційний патент на корисну модель 9805, МПК В65G53/30 Струминний насос. Сьомін Д.О., Роговий А.С.; заявник i патентовласник СНУ імені В. Даля. - № u200503142. заявл. 05.04.2005; опубл. 17.10.2005, Бюл. №10. $-3 \mathrm{c}$.

15. Сьомін Д.О. ВПлив умов входу середовища, що перекачується, на енергетичні характеристики вихрекамерних насосів / Д.О. Сьомін, А.С. Роговий // Вісник Національного технічного університету «ХПІ»: зб. наук. пр. Серія: Гідравлічні машини та гідроагрегати. - 2015. - № 3 (1112). - C. 130-136.

16. Shur M. L. Turbulence modeling in rotating and curved channels: assessing the Spalart-Shur correction / M. L. Shur // AIAA journal. - 2000. - Vol. 38, №. 5. P. 784-792.

17. Alahmadi Y.H. Modified shear stress transport model with curvature correction for the prediction of swirling flow in a cyclone separator / Y.H. Alahmadi, A.F. Nowakowski // Chemical Engineering Science. - 2016. - Vol. 147. - P. 150-165.
18. Yin J. Large eddy simulation of unsteady flow in vortex diode / J. Yin, L. Jiao, L. Wang // Nuclear Engineering and Design. - 2010. - Vol. 240, no. 5. - P. 970-974.

19. Smirnov P.E. Sensitization of the SST turbulence model to rotation and curvature by applying the Spalart-Shur correction term / P.E. Smirnov, F.R. Menter // Journal of Turbomachinery. - 2009. - Vol. 131, no. 4. - P. 041010.

20. Jasak H. OpenFOAM: open source CFD in research and industry / H. Jasak // International Journal of Naval Architecture and Ocean Engineering. - 2009. - 1(2). P. 89-94.

21. Oberleithner K. Formation and flameinduced suppression of the precessing vortex core in a swirl combustor: experiments and linear stability analysis / K. Oberleithner, M. Stöhr, S.H. Im, C.M. Arndt \& A.M. Steinberg // Combustion and Flame. - 2015. - Vol. 162, no. 8. - P. 3100-3114.

22. Syomin D. Mathematical simulation of gas bubble moving in central region of the short vortex chamber / D. Syomin, A. Rogovyi // TEKA. Commission of motorization and energetics in agriculture. LublinLugansk. XB. TEKA Kom. Mot. Energ. Roln. - OL PAN. - 2012. - Vol. 12, no. 4. - P. 279-284.

\section{References}

1. Prikhod'ko A. A. Komp'yuternye tekhnologii $v$ aerogidrodinamike $i$ teplomassoobmene [Computer technologies in aerohydrodynamics and heat- mass exchange], Kiev, Naukova dumka Publ., 2003, 380 p.

2. Solodov V.G. Sovremennoe sostoyanie problemy modelirovaniya krupnomasshtabnoi turbulentnosti [Current state of the problem of large-scale turbulence modeling]. Visnyk NTU «KhPI». Seriya: Hidravlichni mashyny ta hidroahrehaty. 2016. no. 20 (1192), pp. 108-115.

3. Garbaruk A.V., Strelec M.H., Shur M.L. Modelirovanie turbulentnosti $v$ raschetah slozhnyh techenij [Turbulence modelling in calculations of difficult flows], Saint Petersburg, Politehn. University Publ., 2012. $88 \mathrm{p}$.

4. Syomin D., Pavljuchenko V., Maltsev Y., Rogovoy A., Dmitrienko D. Vortex mechanical devices in control systems of fluid mediums. Teka Komisji Motoryzacji $i$ Energetyki Rolnictwa. 2010. Vol. 10. pp. 440-445. 
5. Baranov Yu. D., Blyuss B.A., Semenenko E.V., Shurygin V.D. Obosnovanie parametrov $i$ rezhimov raboty sistem gidrotransporta gornykh predpriyatii [Substantiation of parameters and environment of hydraulic handling systems of mining companies]. Dnepropetrovsk, Novaya ideologiya Publ., 2006, 416 p.

6. Sokolov E.Ja., Zinger N.M. Strujnye apparaty [Jet apparatus]. 3rd ed., Moscow, Jenergoatomizdat Publ., 1989, 352 p.

7. Suslov A.D., Ivanov S.V., Murashkin A.V., Chizhikov Ju.V. Vihrevye apparaty [Vortex Apparatus]. Moscow, Mashinostroenie Publ., 1985, 256 p.

8. Syomin D., Rogovyi A. Features of a working process and characteristics of irrotational centrifugal pumps. Procedia Engineering, 2012, vol. 39, pp. 231-237. doi:10.1016/j.proeng.2012.07.029.

9. Rogovoi A.S. Energeticheskaya effektivnost' pnevmotransportnikh ustanovok. [Energy efficiency of pneumatic installations]. Visnyk SNU im. V. Dalya. 2016, no. 1(225), pp. 189-196.

10. Syomin D., Rogovoy A. Power characteristics of superchargers with vortex work chamber. TEKA. Commission of motorization and power industry in agriculture. 2010, no. 19., pp. 232-240.

11. Syomin D.O., Rogovyi A.S. Eksperimentalnye issledovanija kharakeristic stujnovihrevogo nasosa [Experimental investigations of the characteristics of vortex-fluid pumps], Visnik SumDU, 2005, no 12 (84), pp. 64-70.

12. Rogovyi A.S. Udoskonalyuvannya enerhetychnykh kharakterystyk strumynnykh nahnitachiv. Diss, kand. tekhn. nauk [Perfecting of the power characteristics of inkjet superchargers]. Lugansk, 2007, 193 p.

13. Beck, Jeffrey L. Vortex injection method and apparatus. Patent U.S. no. 4,449,862. 22 May 1984.

14. Syomin D.O., Rogovyi A.S. Strumynnyy nasos [Jet pump]. Patent Ukraine, no. u200503142, 2005.

15. Syomin D.O., Rogovyi A.S. Vplyv umov vkhodu seredovyshcha, shcho pereka- chuyet'sya, na enerhetychni kharakterystyky vykhrekamernykh nasosiv [Influence of transfer mediums input conditions on power characteristics of the vortex chamber pumps]. Visnyk NTU«KhPI». Seriya: Hidravlichni mashyny ta hidroahrehaty, 2015, no. 3 (1112), pp. 130-136.

16. Shur M. L., Strelets M. K., Travin A. K., \& Spalart P. R. Turbulence modeling in rotating and curved channels: assessing the Spalart-Shur correction. AIAA journal, 2000, Vol. 38, no. 5, pp. 784-792.

17. Alahmadi Y.H., Nowakowski A.F. Modified shear stress transport model with curvature correction for the prediction of swirling flow in a cyclone separator. Chemical Engineering Science, 2016, Vol. 147, pp. 150-165.

18. Yin J., Jiao L., Wang L. Large eddy simulation of unsteady flow in vortex diode. Nuclear Engineering and Design, 2010, Vol. 240, no. 5, pp. 970-974.

19. Smirnov P. E., Menter F. R. Sensitization of the SST turbulence model to rotation and curvature by applying the Spalart-Shur correction term. Journal of Turbomachinery, 2009, Vol. 131, no. 4. doi: 10.1115/1.3070573

20. Jasak H. OpenFOAM: open source CFD in research and industry. International Journal of Naval Architecture and Ocean Engineering, 2009, no. 1(2), pp. 89-94.

21. Oberleithner K., Stöhr M., Im S.H., Arndt C. M. \& Steinberg A. M. Formation and flame-induced suppression of the precessing vortex core in a swirl combustor: experiments and linear stability analysis. Combustion and Flame, 2015, Vol. 162, no. 8, pp. 3100-3114.

22. Syomin D., Rogovyi A. Mathematical simulation of gas bubble moving in central region of the short vortex chamber. TEKA. Commission of motorization and energetics in agriculture. 2012, Vol. 12, no. 4, pp. 279-284.

Рецензент: П.Н. Андренко, профессор, д.т.н., НТУ «ХПИ». 